\title{
Mental health problems among clients with substance use problems: a nationwide time-trend study
}

\author{
Kristiina Kuussaari $^{1} \mathbb{1} \cdot$ Karoliina Karjalainen $^{1} \cdot$ Solja Niemelä $^{2,3}$
}

Received: 17 January 2019 / Accepted: 20 August 2019 / Published online: 4 September 2019

(c) The Author(s) 2019

\begin{abstract}
Purpose Mental health and substance use disorders are notable contributors to the global total burden of disease. On a population level, co-occurring mental health and substance use problems are estimated to account for $2-4 \%$. In clinical samples, estimate is even higher. The aim of this study was to examine changes in recognized mental health problems (MHPs) and in the substance use profiles among clients with substance use problems in Finland.

Methods Data concerning individuals with substance use entering Finnish social and health care services during 1 day were collected nationwide at three time-points in 2007, 2011, and 2015. Cross-tabulations and logistic regression were used for statistical analysis.

Results Co-occurring MHPs and substance use problems were common: 56-60\% of the clients with substance use problems were reported to have had MHPs between the years 2007 and 2015. The proportion of MHPs remained rather stable among them. Substance use profiles have changed: the proportion of illicit drug use among those who had MHPs has increased in health care services, social services, and substance use problem services.

Conclusion Co-occurring substance use and MHPs among clients with substance use problems are common, and substance use profile is shifting from using alcohol only towards illicit drug use. This may even bring along more challenges for the treatment system and should be considered in future service planning.
\end{abstract}

Keywords Substance use $\cdot$ Mental health problems $\cdot$ Treatment system $\cdot$ Co-occurrence

\section{Introduction}

Mental and substance use disorders are notable contributors to the global total burden of disease, directly accounting for about $7.4 \%$ of the disease burden worldwide [1]. In general population studies, the prevalence of current mental health disorders among persons with problematic substance use varies depending on the research setting. For example, in the United States, it has been estimated that $3.2 \%$ of the adult population had co-occurring mental illness and substance

Kristiina Kuussaari

kristiina.kuussaari@thl.fi

1 Department of Public Health Solutions, National Institute for Health and Welfare (THL), P.O. Box 30, 00271 Helsinki, Finland

2 Department of Psychiatry, Institute of Clinical Medicine, University of Turku, 20014 Turku, Finland

3 Department of Psychiatry, Turku University Hospital, P.O. Box 52, 20521 Turku, Finland use disorders in the past year [2]. In a French study, the prevalence of anxiety disorders and alcohol use disorder was estimated to be $4.4 \%$, and the prevalence of anxiety disorders and drug use disorder was estimated to be $2.8 \%$ [3]. In clinical samples of substance users seeking help, the co-occurrence of mental health disorders has been estimated to be even higher [see, e.g., 4]. For example, in a cross-sectional nationwide study of clients with substance use problems in the Finnish health care and social services indicated that half of the cases also had recognized mental health problems (MHPs) [5]. Compared to those who have either an MHP or a substance use problem alone, the population with comorbid problems faces a poorer prognosis: more social exclusion, higher rates of poverty, poorer health, multiple morbidity, and early mortality $[1,6,7]$.

Co-occurring MHPs and substance use problems cause remarkable hardships not only to the individuals and their families, but also to the service system [8]. Despite more complex needs, this population faces remarkable barriers to accessing social and health services [9]. One of those 
barriers is an impaired level of functioning due to comorbid problems, in addition to which personal beliefs about treatment providers, as well as stigma associated with MHPs and substance use problems, may lead to challenges in seeking help and entering treatment [9]. However, the service system also constantly fails to provide integrated treatment for both disorders with a low threshold $[9,10]$. In most Western societies, the substance use treatment programmes are separated from health services [11], causing barriers to entering treatment. Sadly, the treatment rates for people with comorbid MHPs and substance use problems are alarmingly low [12].

Despite the well-recognized treatment gap and barriers to treatment, the individuals with comorbid problems seem to be more frequent users of all types of medical services $[8,13,14]$. The individuals with both disorders had, for example, multiple visits to emergency departments [8] and increased rates of psychiatric hospitalisation $[15,16]$. In the United States, the comorbid population had shorter lengths of hospital stay, a greater likelihood of being discharged routinely, and reduced likelihood of being transferred to a short- or long-term facility, indicating an increasing trend of a 'revolving door syndrome' [17].

The time-trend studies examining the service use of individuals with co-occurring MHPs and substance use problems are scarce. Whiteford et al. [1] reported that the global disease burden concerning mental and substance use disorders in general increased by $37.6 \%$ between the years 1990 and 2010. In the United States, the hospital discharges among individuals with severe mental illness and co-occurring substance use almost doubled between the years 1979 and 2008 [17]. Therefore, more information about the trends is needed to plan, develop, and steer the service system, so that it can serve better individuals with co-occurring MHPs and substance use problems.

Utilizing a large and unique data set from a nationwide study conducted in Finland in the years 2007, 2011, and 2015 , the present study aims to contribute to the sparse literature. During this time period, there has been some policy and structural changes in the Finnish social and health care system, especially in the substance use problem and mental health services. The National Plan for Mental Health and Substance Use Work was published in 2009, and one of the plan's main goals was to re-organise the services, so that primary care, basic, and outpatient services were emphasized [18]. One example of these structural changes is an integration of substance use and mental health services carried out in some regions [19]. There has also been great pressure to re-organise social and health care services as a whole in Finland. This reform has been going on almost a decade now, and thus far, no political consensus has been found, how this change should be implemented.

In this study, we aim to answer the following questions: first, have there been changes in the proportion of recognized mental health problems among those who are in treatment or are seeking help or treatment from the Finnish social and health care services because of their substance use? Second, are there changes in MHPs by age, gender, substances used, and services used? Third, are there changes in the substance use profile among those with comorbid MHPs over the study years?

\section{Methods}

\section{Data}

Nationwide Surveys on intoxicant-related cases from 2007, 2011, and 2015 were used as a data source. These 1 day cross-sectional studies have been conducted in Finland every fourth year since 1987. A substance use-related case refers to a case where a client who has used the social and health care services and is known to have problems with different substances or who was under the influence of alcohol or drugs during the visit to the services, or who had an alcoholor drug-related injury. One case does not equate to a single client. One client may have made more than one visit to the services during the time of data collection [5].

The surveys were carried out as postal questionnaires. In 2011 and 2015, an electronic questionnaire was also available. To examine the effect of the data collection mode, the 2011 data collected via paper forms were compared to data collected via electronic forms and no differences in the quality of data were found. Personnel (e.g., nurses, doctors, social workers, and counsellors) in the service units filled in the questionnaire, which included questions about the client's background, the substances used, and the services used. The questions have been almost identical in the different data collections. However, some minor changes and additions to the questions have been made over the years. The data do not include any individually identifiable data [5, 20].

The data were collected from different types of social and health care units. There is a no comprehensive national register of social and health care providers in Finland [see also 5]. This means that the address database used in this study had to be constructed from different sources separately for each data collection. The basis of address database was in 2007 and in 2011 the Register of Institutions in Social Welfare and Health Care (TOPI) maintained by National Institute for Health and Welfare (THL, formerly National Research and Development Centre for Welfare and Health, Stakes). This register contained those service providers that submit data to the HILMO Care Registers, i.e., service providers that provide health care, institutional, housing, and home care services. Private service providers were from the Valveri register, which is maintained by National Supervisory Authority for Welfare and Health (Valvira). Service 
Table 1 Background information

\begin{tabular}{|c|c|c|c|c|c|c|}
\hline \multirow[b]{2}{*}{ Years } & \multicolumn{3}{|c|}{$\operatorname{Men}(n=24,414)$} & \multicolumn{3}{|c|}{ Women $(n=9776)$} \\
\hline & 2007 & 2011 & 2015 & 2007 & 2011 & 2015 \\
\hline Number of participants & 8593 & 8355 & 7466 & 3408 & 3303 & 3065 \\
\hline \multicolumn{7}{|l|}{ Mental health problems (\%) } \\
\hline Yes & 44.0 & 45.5 & 43.0 & 60.0 & 60.0 & 55.1 \\
\hline No & 39.9 & 36.2 & 39.5 & 27.6 & 26.5 & 31.6 \\
\hline No information & 16.1 & 18.3 & 17.5 & 12.4 & 13.4 & 13.3 \\
\hline Median age (years) & 49.0 & 49.0 & 47.0 & 45.0 & 44.0 & 43.0 \\
\hline \multicolumn{7}{|l|}{ Age $(\%)$} \\
\hline Less than 20 years & 2.2 & 2.2 & 2.2 & 4.4 & 5.1 & 3.7 \\
\hline $20-29$ years & 13.5 & 13.0 & 13.1 & 19.2 & 21.5 & 19.1 \\
\hline $30-39$ years & 15.9 & 18.3 & 21.6 & 14.8 & 15.4 & 22.5 \\
\hline $40-49$ years & 20.0 & 18.3 & 17.8 & 21.7 & 17.5 & 14.4 \\
\hline $50-59$ years & 26.4 & 23.3 & 19.3 & 21.7 & 18.8 & 17.0 \\
\hline 60 years or older & 22.0 & 25.0 & 26.0 & 18.1 & 21.8 & 23.3 \\
\hline \multicolumn{7}{|l|}{ Substances used $(\%)^{\mathrm{a}}$} \\
\hline Alcohol & 92.2 & 84.1 & 78.0 & 86.9 & 80.4 & 74.1 \\
\hline Cannabis & 17.2 & 19.0 & 22.4 & 14.3 & 16.8 & 17.3 \\
\hline Amphetamines & 14.6 & 13.2 & 14.0 & 14.1 & 14.9 & 14.9 \\
\hline Opioids & 13.5 & 14.0 & 18.0 & 12.5 & 16.5 & 20.8 \\
\hline Only alcohol & 75.9 & 66.9 & 58.1 & 75.4 & 63.5 & 55.5 \\
\hline Illicit drug use (no IV use) & 5.6 & 4.0 & 5.8 & 5.7 & 4.5 & 5.8 \\
\hline Illicit drug use (IV use) & 18.5 & 29.1 & 36.1 & 18.9 & 32.0 & 38.7 \\
\hline \multicolumn{7}{|l|}{ Service use (\%) } \\
\hline Outpatient services & 60.0 & 56.9 & 62.0 & 67.6 & 63.8 & 68.8 \\
\hline Inpatient services & 40.0 & 43.1 & 38.0 & 32.4 & 36.2 & 31.2 \\
\hline Health care services & 30.2 & 31.9 & 29.1 & 33.2 & 35.8 & 31.4 \\
\hline Social services & 31.7 & 36.2 & 36.0 & 27.6 & 32.6 & 32.1 \\
\hline Substance use problem services & 37.2 & 31.7 & 34.7 & 38.2 & 31.5 & 36.4 \\
\hline Other services & 0.9 & 0.2 & 0.2 & 1.0 & 0.1 & 0.1 \\
\hline
\end{tabular}

Entire data $(n=34,190)$

${ }^{a}$ Individual variable: does not sum to 100 providers that were part of collecting data for $E M C D$ $D A$ 's treatment demand indicator were also included into address database. Municipalities' social services were partly included in TOPI, but this information was complemented by the booklet (Sosiaali ja terveydenhuollon hakemisto 2007 and 2011) that included all social and health care services provided by municipalities. In addition to this, third sector units' (e.g., A-clinics, day centres, and housing services for mental health clients) were drawn from different sources and included in the database [20,21].

In 2015, the basis of address database was Sote organisation register maintained by THL. The register is used for identifying and administering the parties that have joined Kanta Services (digital services for the social welfare and healthcare sector). Sote organisation register includes Valveri register thus covering also private service providers. Otherwise, building up the address database was as described above [22].
Because there is no solid knowledge on how many social and health care service providers there are in Finland, it is impossible to estimate how well different types of service providers were represented in this study. In spite of this, the data offer a unique possibility to examine clients with substance use-related problems widely in different types of social and health care services.

In the analysis, there were all together 34,190 substance use-related cases. This included 12,001 cases from 2007, 11,658 cases from 2011 , and 10,531 cases from 2015 . The exact numbers of substance use-related cases by year and gender are shown in Table 1. 


\section{Measures}

MHPs were measured with the question 'Does the client have any other diagnosed MHP than a substance use-related MHP ${ }^{1}$ The response alternatives were: (1) 'Yes, depression'; (2) 'Yes, other mental health problems'; (3) 'No'; and (4) 'No information'. Those with depression and/or another MHP (response alternatives 1 or 2) were defined as having an other than substance use-related MHP.

Missing information concerning MHP responses were studied in more detail. Among men, there was more missing information on MHPs than among women, and in older age groups more than in younger groups. In social services, the proportion of missing information on MHPs was somewhat higher $(22.8 \%)$ than in other service types (health care services $13.9 \%$; substance use problem services $11.6 \%$ ). The overall picture showed that those who had no information on MHPs had also more missing information in the other variables. However, over the studied time period (2007-2015), the proportion of missing information remained rather stable (except for the social services in which the proportion of missing information increased from 19.4 to $24.4 \%$ ), and thus, those with no information on MHPs were excluded from the further analyses.

Gender (men, women) and age $(<20,20-29,30-39$, $40-49,50-59$, and $\geq 60$ years) were used as background variables. For the analyses, the age groups were further recoded into three age groups ( $<30,30-59$, and $\geq 60$ years).

Substance use was measured with the question 'Which of the listed substances have been used by the client during the last 12 months?' A list of substances was given in the questionnaire (alcohol, surrogate alcohols, solvent, prescription medicines, cannabis, amphetamine, LSD, ecstasy (MDMA), cocaine, heroin, buprenorphine, another opioid, and another illicit drug). Personnel in the service units were asked to register all the substances that the client had used during the last year. Based on that and on the information of the clients' intravenous (IV) drug use, different substance use profiles were formed including categories 'alcohol only', 'illicit drug use (no IV use)', and 'illicit drug use (IV use)'. The first group included those who had used only alcohol (and no other substances), and the latter two included those who had used an illicit drug (or illicit drugs) during the last

\footnotetext{
${ }^{1}$ In 2007 and 2011, the following question was asked: Does the client have any other MHP than a substance use-related MHP? In the instructions, it was emphasized that MHP is reported only if it has been diagnosed. In 2015, the need for diagnosis was raised to the question: Does the client have any other diagnosed MHP than a substance use-related MHP? The assumption is that only those MHPs that are diagnosed are reported in the study.
}

12 months, but may have also used other substances, including alcohol.

The service units were first divided into inpatient and outpatient services. Second, the service units were divided into three more exact service types. Health care services included primary health care centres and hospitals. Social services included social welfare offices, home help services, and housing services. Substance use problem services included substance users' outpatient treatment units, detoxification units, and rehabilitation units.

The distributions of MHPs, age groups, substance use, and service use by gender and year based on the entire data are introduced in Table 1.

\section{Statistical analysis}

Cross-tabulations and logistic regression were used for the statistical analysis. The distribution of age, substance use, MHPs, and service use from 2007 to 2015 were studied using cross-tabulations. Logistic regression analysis was used to estimate whether the change on the proportion of MHPs in the studied time period was statistically significant. An outcome variable in the models was MHP $(0=$ no MHP, $1=$ MHP). Separate models were calculated to estimate the change from 2007 to 2015 and from 2011 to 2015, and all the models were adjusted for age. The results are presented as odds ratios (ORs) and their 95\% confidence intervals (CIs). As there were a statistically significant interaction between MHPs and gender $(p=0.002)$, men and women were analyzed separately. To examine whether the trends in substance use profiles (only alcohol, illicit drug use [no IV use], and illicit drug use [IV use]) differed by MHP in different types of services (health care services, social services, and substance use problem services), the interactions were calculated. A $p$ value $<0.05$ was considered statistically significant. SPSS statistics software version 25 was used for statistical analysis.

\section{Research ethics}

The study protocol of the 'Survey on intoxicant-related cases' has been accepted by the institutional review board of the National Institute for Health and Welfare.

\section{Results}

\section{Changes in the proportion of MHPs in the total study population by gender}

In Tables 1 and 2, it is shown that the level of MHPs was notably higher among women than among men. The proportion of MHPs decreased slightly in the total study population 
Table 2 The proportion of mental health problems (MHPs)

\begin{tabular}{|c|c|c|c|c|c|c|c|c|}
\hline & \multicolumn{2}{|l|}{2007} & \multicolumn{2}{|l|}{2011} & \multicolumn{2}{|l|}{2015} & \multirow{2}{*}{$\begin{array}{l}\text { OR }(95 \% \text { CI }) \\
2007-2015\end{array}$} & \multirow{2}{*}{$\begin{array}{l}\text { OR }(95 \% \text { CI }) \\
2011-2015\end{array}$} \\
\hline & $n$ & $\%$ & $n$ & $\%$ & $n$ & $\%$ & & \\
\hline \multicolumn{9}{|c|}{ MHPs, total ${ }^{\mathrm{a}}$} \\
\hline Yes & 5725 & 57.1 & 5661 & 59.7 & 4830 & 55.5 & \multirow[t]{2}{*}{$0.97(0.92-1.03)$} & \multirow[t]{2}{*}{$\mathbf{0 . 8 5}(0.80-0.91)$} \\
\hline No & 4307 & 42.9 & 3822 & 40.3 & 3877 & 44.5 & & \\
\hline \multicolumn{9}{|c|}{ MHPs, men ${ }^{a}$} \\
\hline Yes & 3701 & 52.4 & 3699 & 55.7 & 3143 & 52.1 & \multirow[t]{2}{*}{$1.03(0.96-1.12)$} & \multirow[t]{2}{*}{$\mathbf{0 . 8 7}(0.81-0.94)$} \\
\hline No & 3360 & 47.6 & 2945 & 44.3 & 2890 & 47.9 & & \\
\hline \multicolumn{9}{|c|}{ MHPs, women ${ }^{a}$} \\
\hline Yes & 2004 & 68.5 & 1945 & 69.4 & 1655 & 63.6 & \multirow[t]{2}{*}{$\mathbf{0 . 8 3}(0.74-0.93)$} & \multirow[t]{2}{*}{$\mathbf{0 . 8 0}(0.70-0.88)$} \\
\hline No & 923 & 31.5 & 859 & 30.6 & 948 & 36.4 & & \\
\hline
\end{tabular}

Statistically significant results are in bold. Cases with no information on MHPs were excluded from the analysis

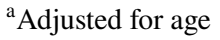

during the period of 2007-2015 (from 57.1 to $55.5 \%$; see Table 2), but the decrease was only statistically significant in the time period of 2011-2015 (from 59.7 to 55.5\%). Among men, the results were rather similar to those for the total study population, whereas among women the observed decrease in MHPs was also statistically significant during 2007-2015.

\section{Changes in the proportion of MHPs by age groups and the substances used}

Table 3 presents the changes in MHPs by different age groups and the substances used. Despite the age group, there was no statistically significant change in the proportion of MHPs among men, whereas among women there was a statistically significant decrease of MHPs in the proportion, both among those aged $30-59$ years and those 60 years old and older (Table 3).

There were also differences in MHPs between men and women regarding the substances used. MHPs had decreased among those men who had illicit drug use (no IV use) problems. Among women, a statistically significant decrease in MHPs was found in those who had used only alcohol (Table 3).

\section{Changes in the proportion of MHPs in different services}

Among men, the proportion of MHPs had decreased in outpatient services as well as in health care services and in substance use problem services. On the contrary, there was an increase in the proportion of MHPs in both inpatient services and social services (see Table 3 ).

Among women, the scene was somewhat different; no increase in the proportion of MHPs was observed. Similar to men, there was a decrease in the proportion of MHPs in outpatient services in both time periods. However, there was also a decrease in inpatient services from 2011-2015 (see Table 3), as well as in health care services. No statistically significant changes were found for other types of services.

\section{Changes in substance use profiles by MHPs in different services}

Finally, we aimed to study if there were changes in the client's substance use profiles regarding MHPs in different types of services. Figure 1 shows that illicit drug use (IV use) had increased in all three service types during 2007-2015 among those who had MHPs, and the observed changes were statistically significant (health care services: $\mathrm{OR}=3.20$, $\mathrm{CI}=2.71-3.79$; social services: $\mathrm{OR}=2.54, \mathrm{CI}=2.01-3.15$; substance use problem services: $\mathrm{OR}=3.46, \mathrm{CI}=2.96-4.03$ ). While illicit drug use (no IV use) has remained rather stable among those who had MHPs in all the service types, the trends concerning the use of alcohol only have decreased (health care services: $\mathrm{OR}=0.42, \mathrm{CI}=0.36-0.48$; social services: $\mathrm{OR}=0.67, \mathrm{CI}=0.57-0.78$; substance use problem services: $\mathrm{OR}=0.41, \mathrm{CI}=0.35-0.47$ ).

Also among those who had no MHPs, these trends were very similar in all three service types: illicit drug use (IV use) has increased and the use of alcohol only has decreased statistically significantly, although illicit drug use was more common among those with MHPs compared to those with no MHPs (data not shown).

\section{Discussion}

The aim of this nationwide study was to examine changes in recognized mental health problems (MHPs) among persons entering social or health care services because of their substance use problems. In addition, we studied changes in 


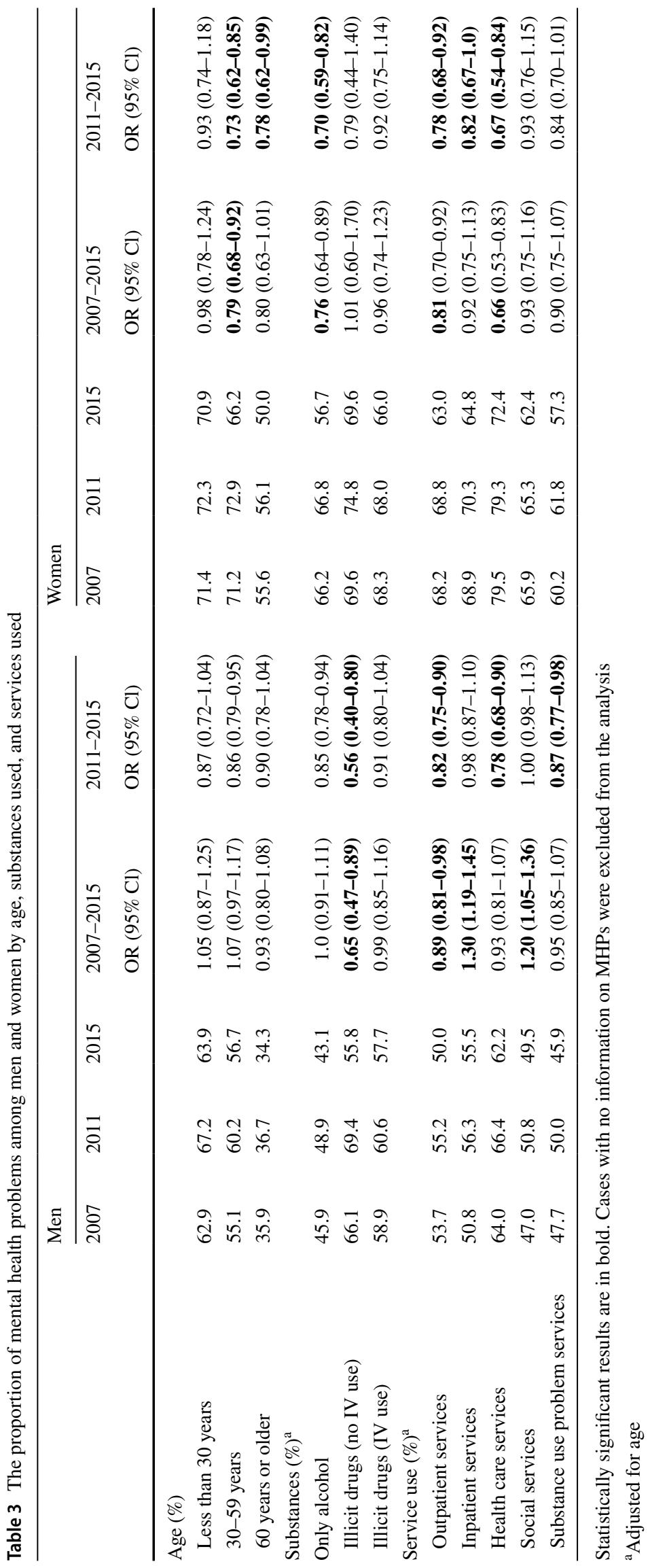




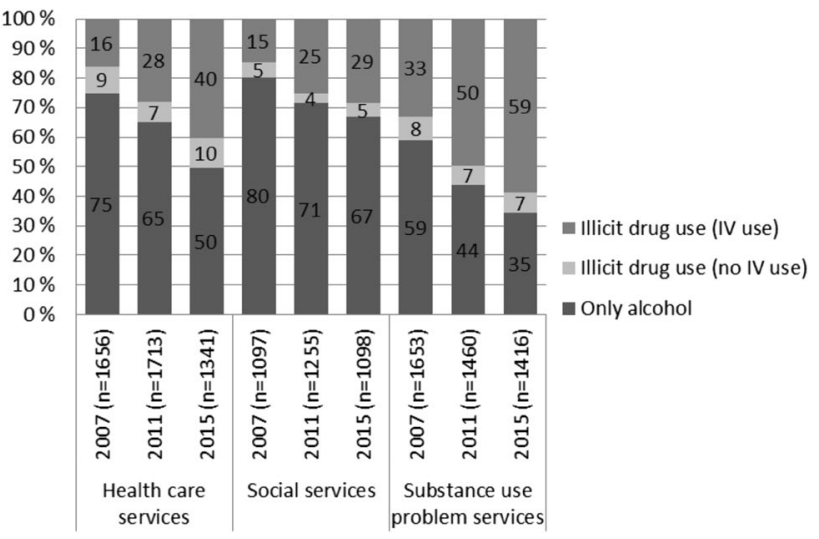

Fig. 1 Services by substances used among those who had mental health problems

their substance use profiles, with and without MHPs. These data were collected during 1 day in Finnish social and health care services at three time-points in 2007, 2011, and 2015.

According to our results, at least $50-60 \%$ of clients with substance use problems have mental health problems, and there seems to be no major changes in prevalence of recognized mental health problems within this population. However, the substance use profile of the service users is shifting from a 'using alcohol only' towards illicit drug use, and this is evident for both clients with or without recognized mental health problems.

Consistent with previous research [5, 23, 24], co-occurring MHPs and substance use problems were common: $56-60 \%$ of the clients were reported to have had MHPs between the years 2007 and 2015. The co-occurring MHPs were more prevalent among women compared to men. Furthermore, the proportion of MHPs remained rather stable among the clients with substance use problems over the study period from 2007 to 2015 . This is in line with the time trends within the Finnish general population, where no major changes in mental health have been reported [25]. In addition, overall alcohol consumption has been decreasing since 2007 in Finland [26], while the use of illicit drugs has remained rather stable, with the exception of the increase in the use of cannabis and ecstasy (MDMA) [27].

However, the trends diverged when analyzed by subgroups. The decrease in MHPs was observed among women, whereas among men, there was even a slight increase in MHPs in inpatient services and in social services. These results may indicate that MHPs indeed have decreased among women and increased among men, especially on those using inpatient services and social services.

Our results are somewhat different compared to the recent time-trend studies elsewhere. In a hospital discharge study from the United States, the co-occurring problems had distinctly increased over the 20 year period [17]. In our study, no such overall trend was observed. This may be explained by different study populations: in our study, social, health, and substance use problem services were included, whereas the study from the United States included only hospital inpatient services. Also the timeframe of the studies was different. All in all, it is difficult to compare our results to the others, since there is a lack of time-trend studies about co-occurring substance use and MHPs. More such studies are needed for better planning, developing, and steering of the service system.

Although illicit drug use was more common in those who had MHPs compared to those with no MHPs, the proportion of illicit drug use has increased at the same pace in both of these groups in all services. Especially, the proportion of clients who used illicit drugs intravenously increased, while a notable decrease in the proportion of those using alcohol only was observed. This most probably relates to the fact that opioid substitution treatment has been increasing in Finland during the study period and persons with intravenous drug use have better access to services [28]. Within the specialized drug use services in Finland, the lifetime prevalence of intravenous use was as high as 76\% [29]. Here, understandably, the rates of intravenous use were substantially lower, as the data collection comprehended service use more broadly. Some increase in opioid and amphetamine use has observed in Finland in the twenty-first century [30]. This may imply that the number of intravenous users among service users may have increased. However, an increasing trend of lifetime intravenous use has not been observed among individuals entering specialized substance use services [29, 31].

According to the results of this study, it seems that among clients with substance use problems, the substance use profile is shifting from using alcohol only towards illicit drug use, regardless of co-existing mental health problems. In previous studies, polydrug use has been shown to be common among help-seeking clients with substance use problems [32], and among clients in specialized drug treatment services [31]. Hence, change in the substance use profiles may bring along more challenges to the service system. Polydrug users are often quite difficult to treat, especially if the person has several other social, somatic, and mental health problems in addition to problematic substance use [33, 34]. This shift in substance use profiles among persons entering services because of their substance use is interesting and needs to be examined in detail in the forthcoming studies. For example, to find out whether the patterns of co-existing mental health problems vary, e.g., among polydrug users, or persons using intravenously amphetamine and opoids.

It is important to notice the special needs of individuals with comorbid MHPs and substance use problems in the treatment system; they do need help for both types of problems. In Finland, services for substance use problems are organised as part of municipalities' social and health 
care system, but there is great variation in service provision both regionally and locally. In Finland, there are more than 300 municipalities, and most of the municipalities are small; only nine municipalities had more than 100,000 inhabitants. In the big municipalities, for example, different types of special substance use problem services are available, whereas in the small municipalities, these services are scarce and the service provision lies on primary level services [35]. Also, some integrated services for persons with severe mental health and substance problems have been developed in Finland, especially in recent years [36]. However, the evidence on the effectiveness of integrated services has been so far contradictory [37]. Irrespective of this, it can be asked whether there are enough necessary and good quality services available for individuals with comorbid mental health and substance use problems, and do they have equal possibilities to receive treatment regionally? Or are there some gaps in the service system that leave these individuals without proper treatment?

\section{Limitations}

The current study is one of few that have studied nationwide changes in observed MHPs among clients with substance use problems. This study utilizes a unique national data set with three time-points from the period 2007 to 2015, and has comprehensive data collection from both social and health care services. However, when interpreting the results, the following limitations should be taken into account: first, it is difficult to estimate the loss of data in this study. It is possible that some of the substance userelated cases have not been recognized in social and health care services when data were collected. It is also possible that some of the service units may not have produced any data for the study [36]. Some of the service units may also have missed the data collection, because in Finland, there is no official nationwide database on social welfare and health care units. Second, as there are no personal identification numbers in this study, it is also possible that some clients may have made more than one visit to the services during the $24 \mathrm{~h}$ of data collection. It is impossible to estimate the amount of these clients $[20,36]$. Third, the proportion of missing information on MHPs was somewhat higher in social services compared to other services, and it had increased over the study period. This might be due to the fact that social services do not operate with International Classification of Diseases (ICD) diagnostic criteria, there are no joint information systems between health and social services and, therefore, there may not be knowledge on the client's mental health status in these services. The missing information on MHPs among social services is important to keep in mind when interpreting the results.

Finally, the reported MHPs were required to be diagnosed, but otherwise the information on MHPs was collected on a generic level, and thus, no detailed information on MHPs was available. The requirement of diagnosis was added into the question concerning MHPs in 2015, but before that it was only mentioned in the instructions. Presumably, the effect of this slight change was minor, since although it could be anticipated that this change would have increased the amount of 'no information' answers, this was not the case (see Table 1). The measure of MHP used in this study may not be as reliable as for example different types of validated clinical assessment tools. Therefore, it is likely that the measure used here underestimates the true proportion prevalence of mental health comorbidity compared to a structured diagnostic interview. On the other hand, the number of false positives is likely to be very low, and the persons with most severe mental health problems are likely to be recognized [38].

\section{Conclusions}

Co-occurring substance use and MHPs among clients with substance use problems are common, and their substance use profile is shifting from a 'using alcohol only' profile towards illicit drug use. This may even bring along more challenges for the treatment system and should be considered in future service planning.

Acknowledgements Open access funding provided by National Institute for Health and Welfare (THL).

\section{Compliance with ethical standards}

Conflict of interest Kristiina Kuussaari: no conflict of interest. Karoliina Karjalainen: no conflict of interest. Solja Niemelä: lecture fees: shire; travel: Sunovion.

Open Access This article is distributed under the terms of the Creative Commons Attribution 4.0 International License (http://creativeco mmons.org/licenses/by/4.0/), which permits unrestricted use, distribution, and reproduction in any medium, provided you give appropriate credit to the original author(s) and the source, provide a link to the Creative Commons license, and indicate if changes were made.

\section{References}

1. Whiteford HA, Degenhardt L, Rehm J, Baxter AJ, Ferrari AJ, Erskine HE, Charlson FJ, Norman RE, Flaxman AD, Johns N, Burstein R, Murray CJ, Vos T (2013) Global burden of disease attributable to mental and substance use disorders: findings from the Global Burden of Disease Study 2010. Lancet 382:1575-1586 
2. Substance Abuse and Mental Health Services Administration (2014) Results from the 2013 national survey on drug use and health: mental health Findings. Substance Abuse and Mental Health Services Administration, Rockville (NSDUH Series H-49, HHS Publication No. (SMA) 14-4887)

3. Leray E, Camara A, Drapier D et al (2011) Prevalence, characteristics and comorbidities of anxiety disorders in France: results from the "Mental Health in General Population" Survey (MHGP). Eur Psychiatry 26:339-345

4. Torrens M, Mestre-Pintó J-I, Damingo-Salvany A (2015) Comorbidity of substance use and mental health disorders in Europe. European Monitoring Centre for Drugs and Drug Addiction, Lisboa

5. Kuussaari K, Hirschovits-Gerz T (2016) Co-occurrence of substance use related and mental health problems in the Finnish social and health care system. Scand J Public Health 44:202-208

6. Whiteford HA, Ferrari AJ, Degenhardt L, Feigin V, Vos T (2015) The global burden of mental, neurological and substance use disorders: an analysis from the Global Burden of Disease Study 2010. PLoS One. https://doi.org/10.1371/journal.pone.0116820

7. Whiteford HA, Ferrari AJ, Vos T (2016) Challenges to estimating the true global burden of mental disorders. Lancet Psychiatry. https://doi.org/10.1016/S2215-0366(16)30026-8

8. Graham K, Cheng J, Bernards S, Wells S, Rehm J, Kurdyak P (2017) How much do mental health and substance use/addiction affect use of general medical services? Extent of use, reason for use, and associated costs. Can J Psychiatry 62:48-56

9. Priester MA, Browne T, Iachini A, Clone S, DeHart D, Seay KD (2016) Treatment access barriers and disparities among individuals with co-occurring mental health and substance use disorders: an integrative literature review. J Subst Abuse Treat 61:47-59

10. Beaulieu T, Ti L, Milloy M-J, Nosova E, Wood E, Hayashi K (2018) Major depressive disorder and access to health services among people who use illicit drugs in Vancouver. Subst Abuse Treat Prev Policy, Canada. https://doi.org/10.1186/s1301 1-018-0142-9

11. UNODC-WHO (2016) International standards for the treatment of drug use disorders. http://www.unodc.org/documents/Internatio nal_Standards_2016_for_CND.pdf. Accessed 14 Jan 2019

12. Wang PS, Lane M, Olfson M, Pincus HA, Wells KB, Kessler RC (2005) Twelve-month use of mental health services in the United States. Results from the national comorbidity survey replication. Arch Gen Psychiatry 62:629-640

13. Urbanoski K, Cheng J, Rehm J, Kurdyak P (2018) Frequent use of emergency departments for mental and substance use disorders. Emerg Med J 35:220-225

14. Urbanoski K, Ingils D, Veldhuizen S (2017) Service use and unmet needs for substance use and mental disorders in Canada. Can J Psychiatry 62:551-559

15. Lambert MT, LePage JP, Schmitt AL (2003) Five-year outcomes following psychiatric consultation to a tertiary care emergency room. Am J Psychiatry 160:1350-1353

16. Stahler GJ, Mennis J, Cottar R, Baron DA (2009) The influence of neighborhood environment on treatment continuity and rehospitalization in dually diagnosed patients discharged from acute inpatient care. Am J Psychiatry 166:1258-1268

17. Manuel J, Gandy ME, Rieker D (2015) Trends in hospital discharges and dispositions for episodes of co-occurring severe mental illness and substance use disorders. Adm Policy Ment Health 42:168-175

18. Kuussaari K, Partanen A (2010) Administrative challenges in the Finnish alcohol and drug treatment system. Nordic Stud Alcohol Drugs BOls 27(6):667-684

19. Stenius K, Tammi T, Kuussaari K, Hirschovits-Gerz T (2015) Vaikuttaako mielenterveys- ja päihdepalvelujen integraatio? Palvelujärjestelmän integraatio tutkimuksen kohteena. In:
Partanen A, Moring J, Bergman V, Karjalainen J, Kesänen M, Markkula J, Marttunen M, Mustalampi S, Nordling E, Partonen T, Santalahti P, Solin P, Tuulos T, Wuorio S (eds) Mielenterveys- ja päihdesuunnitelma 2009-2015. Miten tästä eteenpäin?. Terveyden ja hyvinvoinnin laitos, Helsinki (Työpaperi 20/2015)

20. Nuorvala Y, Huhtanen P, Ahola R, Metso L (2008) Huonoosaisuus mutkistuu - kuudes päihdetapauslaskenta 2007. Yhteiskuntapolitiikka 73:659-670

21. Kuussaari K, Ronkainen JE, Partanen A, Kaukonen O, Vorma H (2012) Kuntoutuksesta katkaisuun. Päihdetapauslaskenta palvelujärjestelmän kuvaajana [The 2011 survey of intoxicant-related cases in Finland: a service system perspective]. Yhteiskuntapolitiikka 77:640-655

22. Kuussaari K, Kaukonen O, Partanen A, Samposalo H, Vorma H (2017) Päihdepalveluiden rakenteen ja työnjaon maakunnittaiset erot vuonna 2015 [Regional differences in substance abuse services in 2015.]. Yhteiskuntapolitiikka 82:262-273

23. Han B, Olfson M, Mojtabai R (2017) Depression care among adults with co-occurring major depressive episodes and substance use disorders in the United States. J Psychiatr Res 91:47-56

24. Lundgren L, Wilkey C, Chassler D, Sandlund M, Armelius BÅ, Armelius K, Brännström J (2014) Integrating addiction and mental health treatment within a national addiction treatment system: using multiple statistical methods to analyze client and interviewer assessment of co-occurring mental health problems. Nord Stud Alcohol Dr 31:59-70

25. Sotkanet.fi. Statistical information on welfare and health in Finland. National Institute for Health and Welfare. https://sotkanet. fi/sotkanet/en/index. Accessed 15 Sep 2018

26. Jääskeläinen M, Virtanen S (2018) Alkoholijuomien kulutus 2017. Terveyden ja hyvinvoinnin laitos, Helsinki (Tilastoraportti 10/2018)

27. Hakkarainen P, Karjalainen K, Ojajärvi A, Salasuo M (2015) Huumausaineiden ja kuntodopingin käyttö ja niitä koskevat mielipiteet Suomessa vuonna 2014 [Drug use, doping and public opinion in Finland: results from the 2014 Drug survey]. Yhteiskuntapolitiikka 80:320-333

28. Partanen A, Alho H, Forsell M, Kotovirta E, Kuussaari K, Mäkelä N, Rönkä S, Selin J, Vorma H (2017) Opioidikorvaushoito on laajentunut ja monimuotoistunut. Lääkärilehti 72:2981-2985

29. Forsell M, Nurmi T (2016) Päihdehuollon huumeasiakkaat 2015. Terveyden ja hyvinvoinnin laitos, Helsinki (Tilastoraportti 14/2016)

30. Ollgren J, Forsell M, Varjonen V, Brummer-Korvenkontio H, Kainulainen H, Karjalainen K, Kotovirta E, Partanen A, Rönkä S, Seppälä T, Virtanen A (2014) Amfetamiinin ja opiaattien ongelmakäytön yleisyys Suomessa 2012 [The prevalence of amphetamine and opioid abuse in Finland in 2012]. Yhteiskuntapolitiikka 79:498-506

31. Nurmi T, Rönkä S (2018) Päihdehuollon huumeasiakkaat 2017. Terveyden ja hyvinvoinnin laitos, Helsinki (Tilastoraportti 31/2018)

32. Kuussaari K, Karjalainen K, Kataja K, Hakkarainen P (2017) Sekakäyttäjät sosiaali- ja terveydenhuollon palveluissa [Polydrug users in social and health care services]. Duodecim 133:2152-2160

33. Ovaska I, Pääkkönen ML, Heinälä P (1993) Päihteiden sekakäyttäjät terveydenhuollon haasteena. Suomen Lääkärilehti 48:2120-2123

34. Pesola EL (2004) Kokemuksia päihteiden sekakäyttäjien hoidosta. Yhteiskuntapolitiikka 69:517-528

35. Stenius K, Kekki T, Kuussaari K, Partanen A (2012) Päihde- ja mielenterveyspalveluiden integraatio - kirjava käytäntö Suomen kunnissa. Yhteiskuntapolitiikka 77:167-175 
36. Samposalo H, Kuussaari K, Hirschovits-Gerz T, Kaukonen O, Partanen A, Vorma H (2018) Tarpeenmukaiset palvelut kaikille? Päihdeasiakkaat sosiaali- ja terveydenhuollon palveluissa Kaakkois-Suomen ja Lapin alueilla [Equal services for all? Substance abusers in social welfare and health care system in south-eastern Finland and Lapland]. Yhteiskuntapolitiikka 83:50-61

37. Savic M, Best D, Manning V, Lubman DI (2017) Strategies to facilitate integrated care for people with alcohol and other drug problems: a systematic review. Subst Abuse Treat Prev Policy. https://doi.org/10.1186/s13011-017-0104-7

38. Sund R (2012) Quality of the Finnish Hospital Discharge Register: a systematic review. Scand J Public Health. https://doi. org/10.1177/1403494812456637 